\title{
Biofabrication and biomaterials for urinary tract reconstruction
}

\author{
Moustafa M Elsawy ${ }^{1-3}$ \\ Achala de Mel' \\ 'Division of Surgery and \\ Interventional Science, Royal Free \\ Hospital, NHS Trust, University \\ College London (UCL), ${ }^{2}$ Division of \\ Reconstructive Urology, University \\ College London Hospitals (uclh), \\ London, UK; ${ }^{3}$ Urology Department, \\ School of Medicine, Alexandria \\ University, Alexandria, Egypt
}

This article was published in the following Dove Press journal:

Research and Reports in Urology

10 May 2017

Number of times this article has been viewed
Correspondence: Achala de Mel

Division of Surgery and Interventional

Science, Royal Free NHS Trust Hospital,

University College London, London, UK

Tel +442074354608

Email demelach@gmail.com

\begin{abstract}
Reconstructive urologists are constantly facing diverse and complex pathologies that require structural and functional restoration of urinary organs. There is always a demand for a biocompatible material to repair or substitute the urinary tract instead of using patient's autologous tissues with its associated morbidity. Biomimetic approaches are tissue-engineering tactics aiming to tailor the material physical and biological properties to behave physiologically similar to the urinary system. This review highlights the different strategies to mimic urinary tissues including modifications in structure, surface chemistry, and cellular response of a range of biological and synthetic materials. The article also outlines the measures to minimize infectious complications, which might lead to graft failure. Relevant experimental and preclinical studies are discussed, as well as promising biomimetic approaches such as three-dimensional bioprinting.
\end{abstract}

Keywords: reconstruction, biofunctionalization, tissue engineering, urinary tract

\section{Introduction}

Reconstructive urology is a subspecialty dealing with repair, restoration, and replacement of parts or all of an organ of the urinary system. ${ }^{1,2}$ Reconstructive surgeons are continuously searching for an ultimate biocompatible material, which when needed can substitute segments of urinary tracts in preference to patient's own tissues. As urologists always implement novel diagnostic techniques and therapeutic procedures to the field, ${ }^{3,4}$ tissue engineering became the up-to-date area of research especially to those involved with reconstructive procedures.

Autologous tissues, such as intestinal segments, skin, and oral mucosa, are the current substitutes for reconstruction. ${ }^{5,6}$ Nevertheless, there are numerous local and systemic complications associated with harvesting those tissues. The complications are clearly outlined in Table 1. Although tissue transfer techniques have been innovated throughout the years, aiming to reach the highest possible level of functional success, the reconstructive armamentarium requires an "off the shelf tissue" to limit patient's morbidity. Modernization of reconstructive urology recently involved the introduction of minimally invasive surgeries such as endoscopic, laparoscopic, and robotic procedures. This realistically decreased patient morbidity, enhanced postoperative recovery, and improved cosmetic outcome. ${ }^{7}$ Nevertheless, despite this "high technology", 8 the functional outcome is rather similar to conventional surgeries. Using a "substitute" that physiologically behaves similar to urinary tissues will provide a practical solution to complex and recurrent cases, which are considered challenging even to experts.

The aim of this study was to highlight how biomimetic approaches are implemented in order to address the unmet needs in developing a bioengineered material that can

Research and Reports in Urology 2017:9 79-92 
Table I Contemporary reconstructive approaches for management of different urinary tract pathologies

\begin{tabular}{|c|c|c|c|c|}
\hline $\begin{array}{l}\text { Hollow urinary } \\
\text { tract organs }\end{array}$ & $\begin{array}{l}\text { The commonest } \\
\text { pathologies }\end{array}$ & $\begin{array}{l}\text { Gold standard } \\
\text { reconstructive techniques }\end{array}$ & $\begin{array}{l}\text { Autologous non-urinary } \\
\text { tissues }\end{array}$ & $\begin{array}{l}\text { Limitations of autologous } \\
\text { tissues }\end{array}$ \\
\hline Urethra & $\begin{array}{l}\text { I. Urethral stricture } \\
\text { 2. Complicated } \\
\text { hypospadias }^{166,168}\end{array}$ & Urethroplasty ${ }^{168-171}$ & $\begin{array}{l}\text { I. Oral mucosal grafts (buccal and } \\
\text { lingual) })^{172,173} \\
\text { 2. Local skin flaps and skin } \\
\text { grafts }^{173}\end{array}$ & $\begin{array}{l}\text { Oral mucosal grafts }{ }^{174,176} \\
\text { I. Donor site morbidity } \\
\text { 2. Pain, bleeding, and infection } \\
\text { 3. Parotid duct injury } \\
\text { 4. Graft contracture } \\
\text { 5. Oral numbness }\end{array}$ \\
\hline Urinary bladder & $\begin{array}{l}\text { I. Bladder cancer } \\
\text { 2. Neurogenic bladder } \\
\text { dysfunction } \\
\text { 3. Detrusor overactivity } \\
\text { 4. Chronic inflammations } \\
\text { and granulomas }{ }^{177}\end{array}$ & $\begin{array}{l}\text { 1. Radical cystectomy and } \\
\text { urinary diversion }{ }^{178} \\
\text { 2. Augmentation } \\
\text { or substitution } \\
\text { cystoplasty }{ }^{179,181}\end{array}$ & Intestinal segments ${ }^{181,183}$ & $\begin{array}{l}\text { Intestine }{ }^{176} \\
\text { I. Metabolic disturbances } \\
\text { 2. Renal function } \\
\text { deterioration } \\
\text { 3. Bacteriuria } \\
\text { 4. Mucous overproduction }\end{array}$ \\
\hline Ureter & $\begin{array}{l}\text { I. latrogenic injuries } \\
\text { 2. Ureteric strictures } \\
\text { 3. Ureteric tumors }\end{array}$ & $\begin{array}{l}\text { Depending on the anatomical } \\
\text { part (upper, middle, and } \\
\text { lower) and the extent of } \\
\text { damage: }{ }^{184} \\
\text { I. Ureteroureterostomy } \\
\text { 2. Transureteroureterostomy } \\
\text { 3. Ureterocalycostomy } \\
\text { 4. Boari flap } \\
\text { 5. Psoas hitch } \\
\text { 6. Autotransplantation } \\
\text { 7. Ileal substitution }\end{array}$ & Intestinal segments 23,185 & $\begin{array}{l}\text { 5. Stones } \\
\text { 6. Perforation } \\
\text { 7. VUR } \\
\text { 8. Carcinoma }\end{array}$ \\
\hline
\end{tabular}

Abbreviation: VUR, esicoureteral reflux.

stand as a future graft for urinary tract reconstruction. This study specially focuses on the fabrication techniques as well as the biofunctionalization strategies, which form the platform technology for regenerating urological tissues. The physiochemical and biological properties of materials can be tailor-made to match those of the urinary tract. The three elements of urinary tract regeneration are the cells, the scaffolds, and the physiological environment for tissue growth and survival. Classically, the approaches involve either cellbased therapy alone or implantation of a biomatrix whether or not seeded with cells. ${ }^{9}$

\section{Properties of an ideal biomaterial for urinary tract substitution}

Broadly speaking, bioengineered tissues must be biocompatible, biodegradable, and well vascularized. ${ }^{10,11}$ Regenerated urinary tract tissues should be characterized by unique physical and biological properties to match the physiological functions of urine storage and emptying. ${ }^{12,13}$ Previous studies, as in bladder tissue engineering, showed that the biodegradation process reflects tissue remodeling. Eventually, if the degradation process follows the rate of regeneration within a suitable timeframe, this will result in a terminally differentiated functional urothelium. ${ }^{14}$ Moreover, the material has to support adequate smooth muscle regeneration. This is best accomplished by seeding the scaffold with smooth muscle cells. ${ }^{15}$ Achieving an appropriately thick muscular layer will allow the regenerated tissue to be robust, withstanding rupture if overfilled with urine. It is also of equivalent importance for effective contractions.

Structural integrity and mechanical stability are both necessary for surgical handling of tissues, as well as to avoid diverticulum formation when subjected to extreme voiding pressures. Although strength is imperative, the material must also be compliant to accommodate increasing volumes of urine during the bladder storage phase without generating high pressures ${ }^{16}$ Compliance could be adjusted by tailoring the mechanical properties of the material to simply stretch. This pliability is also critical for urethral reconstruction, in order to anastomose it freely with native tissues in a watertight fashion, ensuring a good blood supply. This is vital in penile urethral substitution, where shearing of the material could result from stress forces of erections. ${ }^{17}$

Unquestionably, the material must be completely impermeable to urine, as urine is cytotoxic to the growing cells and urine leakage can subsequently lead to a devastating urinoma. ${ }^{18}$ Furthermore, the surface of the material in contact with urine should resist the formation of bacterial biofilms and encrustations, avoiding long-term complications on the upper urinary tract. ${ }^{13}$

Table 2 and Figure 1 summarize the ideal properties for biomaterials substituting urinary tissues. 


\section{Silk fibroin (SF)}

SF is naturally derived from Bombyx mori cocoons. It is an evolving material for use in urinary reconstructive procedures. It has excellent inherent biocompatibility with less immunogenic and inflammatory reactions, compared to other biological materials. The mechanical properties are superior in terms of elasticity and stability of its shape. ${ }^{34}$ SF can also be electrospinned turning it to a highly porous scaffold. This unique feature is desired for cell-seeded approaches. Seeding SF with diverse cell types was successful in various preclinical urological studies. ${ }^{35-39}$ Electrospinned SF showed perfect biological and mechanical tissue performance when used in augmenting the bladder of a rabbit model. It was efficient at generating functional smooth muscle regeneration compared to BAM. ${ }^{40}$

Electrospinned SF was also useful in promoting nerve regeneration. Nerve guidance conduits made from silk fibroin and poly(lactic-co-glycolic acid (PLGA) through electrospinning and weaving were able to promote and maintain Schwan cell growth in vivo in rabbits. ${ }^{41}$ This could be applied in the near future as a biomaterial to promote nerve tissue regeneration for bladder or ureteric engineering. The aim was to have a functional tissue for bladder contractions or ureteric peristalsis.

In a recent urethral study, ${ }^{39}$ acellular bilayered silk fibroin was used as an onlay patch in a rabbit urethral model. It was capable of supporting urethral regeneration similar to conventional SIS scaffolds, but with much less immunogenicity. ${ }^{39}$

\section{Synthetic polymers}

Synthetic polymers include polycaprolactone (PCL), polylactic acid (PLA), PGA, PLGA, and polyurethane (PU). Since their Food and Drug Administration (FDA) approval, they were extensively tested in various areas of biomedicine. ${ }^{11}$

They have myriads of advantages, making them theoretically superior for urinary tract applications. Their supply is limitless. Furthermore, porosity, ultrastructure and surface area to volume, elasticity, and degradation can be well handled to match the original tissues. Nevertheless, synthetic polymers do lack biological recognition. Unlike biological materials, they do not possess inherent growth factors and proteins mandatory for cellular interactions. ${ }^{19}$

\section{Biofabrication of the urinary tract}

ECM consists of various proteins, most importantly collagen, elastin, and glycosaminoglycan, ligands, and growth factors. They provide the structural support and tensile strength, as well as cellular adhesions and signaling. ${ }^{42,43}$
Mimicking urinary ECM can be achieved by modifying and assembling the biomatrix structure at the micro or nano scale. This changes its physical and biological behaviors to adapt to the urinary environment.

\section{Strategies to match the physical properties}

\section{Hybrid biomaterials}

Combining synthetic and naturally derived or natural biomaterials to manufacture a hybrid material is well known for utilizing the desirable properties of each. Biological scaffolds as BAM will enhance the stretchability of the graft, as it is rich in collagen type 4 . Synthetic polymers, on the other hand, will maintain the mainframe structure of the tissue. A contemporary limitation in blending different materials is the difference in their structure chemistry. However, chemical modifications to conjugate them together were successful but potentially altered their biological behavior. Manufacturing techniques, such as electrospinning, have been successful in mechanically stabilizing hybrid polymers, which in turn supported the growth of different cell types. Electrospinned PLGA fibers were efficaciously mixed with BAM to support the growth and differentiation of bladder smooth muscle cells. ${ }^{44}$ In an experimental study involving, ${ }^{45}$ a hybrid material composed of equal amounts of PLGA and chitosan showed similar mechanical results to SIS controls. Moreover, canine smooth muscle viability was superior to the controls. ${ }^{45}$

\section{Modifiable scaffolds}

Recently, nanostructured titanium dioxide $\left(\mathrm{TiO}_{2}\right)$ scaffolds were tested as new nanocomposites for possible urological applications. $\mathrm{TiO}_{2}$ scaffolds of different shapes such as tubes, wires, spheres, and porous membranes resulted in a terminally differentiated multilayered urothelium 3 weeks after seeding with porcine urothelial cells. These results highlighted their ability to adapt to different contours without changing their biocompatibility. $\mathrm{TiO}_{2}$ scaffolds represent a good nominee for future widespread applications in urinary reconstruction. ${ }^{46}$

\section{Strategies to match the biological properties \\ Topographical modifications \\ Surface roughness}

The surface topography of scaffolds is crucial for cellular growth and differentiation. ${ }^{47,48}$ Synthetic nanocomposites possess the advantage of tailoring their structure at the nano and submicron scales. Increasing polymer surface roughness improves its attachment to cellular proteins, a necessary affair 
for urothelial cell adhesion. ${ }^{47}$ Poly-carbonate-urea-urethane was treated in an experimental study ${ }^{50}$ to increase its surface roughness by adding carbon nanotubes. This resulted in an increased adsorption of fibronectin without altering the surface chemistry of the polymer. ${ }^{49}$

An alternative approach to modify material roughness is chemical modification of the polymer fibers by alkaline hydrolysis. This modification also improves polymer biocompatibility. ${ }^{50}$ However, chemical etching using sodium hydroxide hydrolysis is associated with change in the chemical composition and architectural orientation of synthetic polymer fibers. Therefore, the mechanical properties will change accordingly. ${ }^{50,51}$ For that reason, additive manufacturing (AM), which will be discussed in the next section, has the advantage of controlling the material surface roughness without chemical processing. In a recent bone tissue-engineering study, ${ }^{52} \mathrm{AM}$-guided 3D selective laser melting of the polymer has produced the optimal surface roughness for cell adhesion. The material morphology and visual observations were assessed using scanning electron microscopy and 3D micro computed tomography $(\mathrm{CT}) .^{52}$

\section{Pore geometry}

A morphological feature of utmost importance for cell seeding is pore geometry. Optimum pore size, number, and interconnectivity are essential for the regenerating tissues to endure. The presence of pores provides a pathway for the diffusion of nutrients to the cells as well as for the elimination of unnecessary metabolic wastes. ${ }^{53,54}$ Cellular attachment and proliferation require pore sizes ranging between 100 and 400 $\mu \mathrm{m}$ and should involve at least $75 \%$ of the scaffold surface area. ${ }^{55}$ Various methods were described in the literature to produce a $3 \mathrm{D}$ porous scaffold. Conventional fabrication techniques for porosity of the scaffold such as salt leaching, gas forming, phase separation, and freeze-drying cannot control the microarchitecture of the scaffold. This issue could be solved using a computer-assisted AM approach. ${ }^{56}$

\section{Relation between surface topography and stone deposition}

A chief concern for using synthetic polymers in urological reconstruction is their exposure to urine, as the bladder is the main reservoir of urine. Therefore, the urine transit time is at its maximum. In some metabolic conditions, such as hypercalcuria and oxaluria, the calcium and oxalate crystal supersaturation permits nucleation of stone crystals. Consequently, it was imperative to study the relation between the topography of scaffolds and stone deposition. Chun et al ${ }^{58}$ studied the effects of nano-rough surface and the presence of submicron pores of PLGA and PU polymers on both urothelial cell adhesion and calcium oxalate deposition. An increased urothelial cell density was evident in the highly porous scaffold compared to nonporous ones. In addition, higher amounts of both calcium and oxalate crystals were deposited into submicron pores of the nano-rough PU inhibiting its crystallization in solution. The amount of calcium adsorbed on the submicron PU pores was four times higher than that on conventional PU. The authors concluded that submicron porous nano-rough PU prevented calcium oxalate crystal nucleation and formation. ${ }^{57}$

\section{Influence of fabrication techniques on scaffold topography \\ Conventional methods}

Several classic assembly techniques aim to modify synthetic polymer fibers for optimum cell anchoring, which include electrospinning (ES), thermally induced phase separation, self-assembly, and wet spinning. ES is the most widely used technique. Unfortunately, it lays down smaller fibers with haphazardly arranged pores, not in favor of cell penetration. However, the morphology can be better optimized when ES is combined with other techniques like AM. ${ }^{58}$

\section{AM}

Unlike conventional techniques, AM-3D printing-rapid prototyping controls scaffold microarchitecture with greatest precision. ${ }^{59}$ AM builds scaffold layers from ground level. It also uses a variety of raw materials to customize the scaffold architecture. The process is assisted with the aid of a computer software (computer-aided design [CAD]) for prototyping models aiming to mimic the original structure of the tissue or organ. Implementation of computer-designed models to direct scaffold fabrication is referred to as computer-assisted tissue engineering. It is a groundbreaking tool recently introduced to biomaterial designing technology. Several AM methods are available now on the market, which include fused deposition modeling, selective laser sintering, stereolithography, precision extrusion deposition, and 3D printing. ${ }^{60,61}$

Hybrid AM combines AM techniques with conventional methods, most commonly ES. It aims to integrate materials at the assembly or technique levels and, accordingly, gain a dual benefit. ${ }^{62}$ Hybrid AM in the field of bone and cartilage tissue engineering successfully manufactured 3D hierarchical structures with high porosity. ${ }^{63-66}$ Subsequently, it was extended even further to involve the field of soft tissue engineering such as skin, vascular, and nerve regeneration. ${ }^{67-69}$ 
Although AM approaches are superior in designing and optimizing polymer architecture, the range of suitable biomaterials available for processing is limited with respect to soft tissue engineering. For example, hydrogels are attractive materials for soft tissues, but their processing and maintaining their 3D integrity are challenging with several AM techniques. ${ }^{70}$

\section{Incorporation of bioactive molecules into the scaffold}

Several studies used exogenous trophic factors to biofunctionalize scaffolds, particularly in bladder tissue engineering. ${ }^{11-73}$ Bioactive factors are categorized into 1) natural ECM proteins (GAGs) such as collagen, laminin, and fibronectin; 2) short peptide sequences such as RGD and YIGSR; 3) growth factors such as vascular endothelial growth factor (VEGF), insulin-like growth factor 1 (IGF-1), basic fibroblast growth factor (bFGF), platelet-derived growth factor (PDGF), and hyaluronic acid (HA); and 4) synthetic molecules. Loading scaffolds with bioactive agents creates a microenvironment simulating ECM. This environment allows cells to grow, interact, and differentiate into complex tissues, specifically urothelial, smooth muscle, vascular, and nerve tissues. ${ }^{74,76}$ Bioactive molecules can be incorporated into the bulk of the polymer either during synthesis or by surface conjugation.

\section{Growth factors}

Basic fibroblast growth factor (bFGF) was chemically crosslinked to BAM to control its release. FGF promoted human fibroblast proliferation after implantation to a rat bladder reconstruction model. ${ }^{76}$ The PLGA nanoparticles were used as delivery agents loaded with HA to modify porcine SIS scaffolds for bladder augmentation in Beagle dogs. In that study, full thickness regeneration was noted in all canine models. ${ }^{77}$ Recently, a study ${ }^{77}$ used PLGA-loaded nanoparticles to deliver VEGF onto BAM to augment bladder in rabbits. The microvessel density in the experimental group was significantly higher compared to the controls. Moreover, shrinkage of the graft decreased by $27 \%{ }^{78}$

IGF-1 enhances smooth muscle regeneration. A recombinant variant was immobilized within the polymerization process of a 3D fibrin matrix. This was effective in inducing smooth muscle proliferation both in vitro and in vivo. ${ }^{79}$ VEGF is also a growth molecule that recruits and enhances proliferation and survival of endothelial cells, promoting vasculogenesis. ${ }^{80}$ VEGF was delivered on its own or combined with other growth molecules to miscellaneous scaffolds for bladder augmentation in animal models. The histological outcome was appealing in terms of enhanced vessel, nerve, urothelial, and smooth muscle cell regeneration. The functional outcome was also promising as there was a marked increase in bladder capacity and compliance. ${ }^{78,81-83}$

Combining different recombinant growth factors produces a positive synergistic effect on bladder tissue regeneration. Yang et al ${ }^{83}$ compared in vitro the biological effects of eight different growth factors on proliferation, migration, and wound healing of three cells. The results indicated that PDGF, epidermal growth factor, and VEGF were the most exciting growth factors for improving human bladder smooth muscle, urothelial, and vascular endothelial cell activities. Those findings proposed their potential use for bladder regeneration and angiogenesis ${ }^{84}$ Sharma et al ${ }^{85}$ bioactivated the elastomer poly(1, 8-octanediol-co-citrate) films (POCfs) with heparan sulfate, generating a heparin-binding POCf (HBPOCf), subsequently liberating proangiogenic factors such as VEGF, FGF2, and IGF-1 from HBPOCf. The in vitro analysis, after $\sim 1$ month, demonstrated topographical modifications together with a threefold increase in vessel density compared to the controls. The in vivo studies were conducted after subcutaneous implantation of the biofuntionalized scaffolds (HBPOCf-VEGF) within the dorsa of nude rats. Angiogenesis was further confirmed by $\mathrm{CD} 31$ and VWF immunostaining of the implanted sites. ${ }^{85}$

\section{Short-sequence peptides}

Short-sequence peptides such as RGD and YIGSR are used in regenerative medicine. ${ }^{86}$ They act by attaching the cytoskeleton by integrins to the ECM immobilizing them, allowing better adhesion and growth. ${ }^{87}$ RGD-modified PLGA scaffolds demonstrate a better smooth muscle cell adhesion compared with unmodified ones. ${ }^{88}$

\section{Influence of surface chemistry on cell-biomaterial interaction}

Modifying the material surface biochemistry can render it receptive for cellular attachment. ${ }^{89}$ Hydrophilic surfaces are preferred for better interaction with urothelial cells, which is achieved by adding functional groups onto the polymer surface. Various chemical and physical methods were used to treat the polymers in order to achieve this goal.

Uchida et al ${ }^{89}$ described layer-by-layer (LbL) modification of poly(carbonate urethane) urea (PCUU) scaffold surface by adding fibronectin and gelatin layers. The modified scaffold surfaces demonstrated higher affinity with urothelial and bladder smooth muscle cells compared to uncoated PCUU. ${ }^{90}$ 
Garcia-Garcia et $\mathrm{l}^{91}$ treated the surface of poly(3-hydroxybutyrate-co-3-hydroxyvalerate) by sodium hydroxide hydrolysis. It resulted in functionalization of the polymer with $-\mathrm{NH}_{2}$ and -COOH groups. Covalent attachment of the YIGSR sequence increased the hydrophilicity of the polymer surface, resulting in improved adhesion and growth of porcine urothelium. ${ }^{91}$ The same group expanded their work further on a different polymer, poly(3-hydroxybutyrate-co-3-hydroxyhexanoate), using sodium hydroxide hydrolysis and ethylenediamine aminolysis in aqueous and isopropanol media. ${ }^{92}$

One of the main advantages of plasma gas treatment of polymers is the introduction of functional groups to its surface. However, there is a concern of changing their physiochemical properties. ${ }^{93,94}$ Pandiyaraj et a ${ }^{94}$ used plasma-treated thin transparent $\mathrm{TiO}_{2}$ film coated on the surface of a flexible poly(ethylene terephthalate) film. It resulted in increased hydrophilicity by adding a negatively charged group, as well as increased surface roughness. This adjustment was not cytotoxic to the cultured osteoblasts. Of interest, an antibacterial activity against Staphylococcus group of bacteria was noted. ${ }^{95}$

Ultraviolet cross-linking technology uses the same principle as plasma. Although it has been the focus of several vascular and cardiac tissue-engineering studies, ${ }^{96-98}$ several biocompatibility and mechanical issues limited its use for soft tissue engineering. ${ }^{99}$

The role of cell seeding and cell-scaffold interaction Autologous cells

Urothelial cells are attractive for cellularizing biomatrices for bladder and urethral reconstruction. As they are autologous, there is a low risk of inducing autoimmune reactions. ${ }^{100}$ Moreover, their isolation, as well as their method of culture, is well established and described liberally in the literature. ${ }^{101,102}$ However, their use may not be proper in some diseases. ${ }^{103}$ Also, harvesting cells from patients with urothelial carcinomas carries the risk of tumor recurrence. ${ }^{104}$ Moreover, Subramaniam et al highlighted that urothelial cells derived from bladders with neuromuscular dysfunction revealed poor regenerative capability when cultured in vitro. ${ }^{105}$

Another alternative autologous epithelial cell that is under focus of research is tissue-engineered buccal mucosa. It is showing promising results in preclinical and clinical trials for future implication as an alternative cell source for urethral tissue engineering. ${ }^{35,106,107} \mathrm{In}$ a recent clinical study involving 12 patients, stricture recurrence in the anterior urethra occurred in two patients only. ${ }^{108}$ However, researchers should extend the follow-up period to include a higher number of patients and consider different stricture etiologies for further trials.
Stem cells (SCs)

SC application in reconstructive urology is unveiling hopeful results. ${ }^{109}$ Adult mesenchymal stem cells (MSCs) are more favorable than fetal SCs because they are not associated with teratoma formation, nor the ethical dilemma surrounding them. ${ }^{110}$ They are harvested from different sources (eg, bone marrow, adipose tissue, and skeletal muscles). They have an exquisite pluripotentiality to differentiate into multiple cell lineages, including osteoblasts, chondrocytes, myocytes, adipocytes, and neurons. ${ }^{11}$ Adipose-derived stem cells (ADSCs) are one of the most promising cells for urological tissue engineering, mainly due to their high abundance in and their simple isolation from patients. ${ }^{112}$

Urine-derived stem cells (UDSCs), similar to MSCs, have the pluripotentiality to differentiate into several tissue types, including urinary structures. They do not necessitate aggressive techniques for sampling and are cost-effective. They also have an immune regulatory function as well as angiogenic properties. ${ }^{113}$ Both MSCs and UDSCs exhibit paracrine effects by secreting various cytokines and growth factors such as hepatocyte growth factor, nerve growth factor (NGF), glial growth factor, IGF-1, and VEGF. The paracrine effects of SCs play a major role in tissue regeneration by exhibiting both antifibrotic and angiogenic effects. ${ }^{114}$

Induced pluripotent stem cells (IPSCs) are genetically bred SCs and are generated from somatic cells by inducing the expression of different transcription factors. They could offer several advantages over the adult SCs while maintaining the plasticity of embryonic SCs. ${ }^{109}$ They have a marvelous self-regenerative ability and also can differentiate into diverse cell lineages. They were reported successfully for the first time for their use in prostate, bladder, and ureter regenerative applications by reprograming stromal cells into an embryonic SC-like pluripotent state. ${ }^{115}$

The functional aspect of the regenerated tissues, especially the urinary bladder, should not be underestimated. As previously mentioned, the most important function of the bladder is to effectively contract and empty urine. This requires proper smooth muscle and nerve regeneration. Detrusor muscle is the major functional tissue of the bladder, but has to be well innervated by sympathetic and parasympathetic nerve supply. This enables the bladder to coordinate its storage and emptying. ${ }^{109,116}$ UDSCs and MSCs have both shown in numerous studies that they are a well-established source for detrusor muscle engineering, and exhibit phenotyping features similar to bladder smooth muscle cells. ${ }^{17-120}$ A recent study involving ADSCs with a BAM graft showed an enhanced detrusor muscle, neuronal regeneration, and 
increased bladder capacity in a rat bladder model. ${ }^{24}$ This indicates that ADSCs are very promising in bladder regeneration. ${ }^{24}$ Biofunctionalized scaffolds with NGFs and MSCs were effective in promoting nerve regeneration in bladder TE. ${ }^{116,121}$ Further strategies for the functional aspects will be discussed later in the section of promising strategies.

\section{Antimicrobial surface properties}

Urological diseases necessitating reconstruction, such as urethral stricture and neurogenic bladders, are chronic in nature and are associated with urine stasis. Frequently, they are complicated by urinary tract infections, ${ }^{122}$ which are usually polymicrobial and multidrug resistant. ${ }^{123-125}$ Similar to urethral catheters and ureteric stents, colonization with virulent uropathogens on the inner surface of biomaterials forms a sturdy biofilm resistant to the action of standard antibiotics and disinfectants. ${ }^{126,127}$ Urea-splitting bacteria, particularly Proteus species, can deposit encrustations on the synthetic material surface. ${ }^{128-131}$ Those encrustations can theoretically block the lumen of tubularized synthetic scaffolds. For that reason, antibiofilm modifications are essential preventive strategies to maintain the patency of synthetic tubular grafts. Nanostructured surfaces may influence the behavior of bacteria on the surface of biomaterials. ${ }^{132}$ Bacterial adherence and biofilm formation onto these surfaces vary widely according to the biological properties of the species and the nano-topographical features of the surface. ${ }^{133,134}$

\section{Noble metals}

Noble metals such as silver and gold have excellent inherent properties for antimicrobial applications. Biocompatibility, hydrophobicity, and slow development of resistant strains make them the best surface agents for long-term use in the urinary tract. Nevertheless, their cost-effectiveness, biodistribution profile, and possible systemic toxicities need to be addressed for future lifelong use in urinary reconstruction. ${ }^{135}$

An experimental study involved surface functionalization of nylon catheters by coating them with a $100 \mathrm{~nm}$ layer of silver nitrate. ${ }^{136}$ A sustained release of silver particles was observed at the implantation sites over 10 days. This modification prevented the biofilm formation of various gram-positive and gram-negative bacterial uropathogens, as well as Candida species. The in vivo analysis in male mice revealed that the biodistribution of silver was stable. Only $20 \%$ accumulated locally in the implantation site with $<1 \%$ systemic organ distribution. ${ }^{137}$ Also, functional gold nanoparticles effectively suppressed the growth of multidrug-resistant uropathogens in vitro. ${ }^{136}$

\section{Nitric oxide (NO) donors}

NO is known to have an antibacterial activity by suppressing bacterial adhesion and causing dispersion of the attached biofilms. ${ }^{138,139}$ Slow release of NO can be accomplished by surface impregnation of NO donors into synthetic polymers. A novel study by Colletta et al $^{139}$ tested the possibility of using S-nitroso-N-acetylpenicillamine (SNAP)-impregnated silicone Foley catheters for the prevention of catheter-associated urinary tract infections (CAUTIs). SNAP is a synthetic NO donor able to generate NO at stable levels. ${ }^{141}$ It is also able to suppress the formation of biofilms of two well-known microorganisms triggering CAUTIs and urinary device infections, Proteus mirabilis and Staphylococcus epidermidis. ${ }^{140}$

\section{Promising strategies}

Tissue/organ engineering is undergoing a major shift. Smart biomaterials and organ bioprinting are promising research areas for biomedical applications. They can overcome the current limitations of materials used in soft tissue and complex organ reconstruction.

\section{Smart polymers}

Smart or stimulus-responsive biomaterials sense the changes in microenvironments, such as the $\mathrm{pH}$, temperature, or mechanical stimuli, and consequently respond by changing their properties. ${ }^{142,143}$ In general, smart biomaterials that are clinically relevant and currently used for some medical applications are smart hydrogels, shape-memory polymers (SMPs), and stimulus-responsive nanoparticles.

SMPs are implemented in various medical applications such as devices for minimally invasive surgery, the delivery of therapeutics, and scaffolds for tissue engineering. ${ }^{144}$ The earliest application of SMPs in urology was their integration in stents with thermo-expandable shape-memory properties. The stents were used to circumvent many ureteric, urethral, and prostatic gland diseases. ${ }^{145,146}$ Regarding regenerative medicine applications, SMPs were experimented in various vascular and bone tissue engineering/regenerative medicine studies. ${ }^{147-149}$ Their biocompatibility with cells and their tailored mechanical properties are promising. SMPs can respond to different stimuli by changing their shapes and dimensions; subsequently, on removal of the stimulus, they can regain their original shape. ${ }^{150}$ For that reason, it is relevant to explore the concept in response to urinary stimuli. In bladder reconstruction, these polymers can be tailored to change their shape in response to bladder filling, urine $\mathrm{pH}$, or temperature and subsequently regain back their original shape after emptying. For urethral applications, if used as implants in the penile 
urethra, they can stretch with penile erections, and then can shrink back to their original shape after detumescence.

Electroconductive polymers are also an interesting subset of smart polymers and can be very beneficial for bladder tissue regeneration. Electroactive PU polymers have shown great potentials for Schwan cell regeneration and muscle cell expression. This could help growth of detrusor and bladder nerve regeneration for effective contractions. This might be further maintained by a sort of electromagnetic stimulation. ${ }^{116,151-154}$ Electroconductive natural polymer-based hydrogels can compatibly be suitable for bladder bioprinting. ${ }^{155}$

\section{D bioprinting}

Tissue bioprinting involves direct printing of living tissues in a 3D manner in order to produce a complex structure simulating the original organs. Unlike other AM methods, it involves incorporation of cells, growth factors, and biomaterials simultaneously in a one-step approach. ${ }^{156}$ Recently, Kang et a ${ }^{156}$ reported a novel 3D bioprinting system able to fabricate human-scale tissue constructs of any shape. The integrated tissue-organ printer (ITOP) is a smart technology that involves the integration of medical imaging data from CT or magnetic resonance imaging scans to a computer software. The software analyses the anatomical defects, translating them to a $3 \mathrm{D}$ CAD model. A visualized motion program controls the bioprinter nozzles to dispense cell-laden hydrogels within specific areas of biodegradable polymers, such as PCL. This technique controlled several tissue microarchitectures in a precise manner resulting in uniform pore geometry. The ITOP system successfully printed the calvarial bone, ear cartilage, and skeletal muscles. Cell viability was not affected by the printing process when tested using sensitive assays. It is expected that this technology will soon be long-drawn-out to print more complex tissues and organs. ${ }^{157}$

Another group ${ }^{157}$ used a computer-aided four-headed 3D printing system to design and print heterogeneous tissue/organ constructs. The system used cell-laden hydrogels and thermoplastic polymers such as PCL, PLA, and PLGA. The algorithm using the multiple-head tissue/organ building system (MtoBS) is an LbL process that is able to lay down two or more kinds of cells per gel solution. Products were well integrated mimicking original tissues both internally and externally. It was able to print external ear, kidney, and tooth with diverse tissue components. ${ }^{158}$ In another study ${ }^{159}$ the 3D bioprinters utilized decellularized ECM bioinks to print tissue analogs. This technique was versatile. Different tissues such as cartilage, heart, and adipose were successfully printed. The tissue constructs demonstrated prolonged stability and cellular compatibility in all experimental assays. ${ }^{159}$
The earliest application of 3D printing in the field of urology was for tissue simulation as a surgical education tool. It was also used for prototyping cancer models for correlation between imaging and histology in prostate and renal cancers. ${ }^{160-163} \mathrm{~A}$ recent study by Zhang et al, ${ }^{164}$ which is considered the first, described 3D bioprinting of the urethra. This group succeeded in using the previously mentioned ITOP system to bioprint a composite urethral scaffold. It consisted of a PCL/PLCL-blended porous spiral scaffold together with two types of autologous cells (rabbit bladder urothelial and smooth muscle cells) dispensed in fibrin hydrogel of which a thorough in vitro assessment of the biomimetic mechanical properties and cell growth environment was carried out. The results of the study revealed that the biomaterial mechanical properties were equivalent to native rabbit urethra. Cell viability and proliferation were maintained sufficiently in the hydrogel. This study provided a strong foundation for future studies on 3D bioprinting of the urethra but has to be tested first in animal models. ${ }^{164}$

Although tissue bioprinting appears ideal for tissue/ organ reconstruction, its use is still experimental. The limited supply of materials, non-optimized mechanical properties, infrequent preclinical studies, time consumption, and high cost restrict its current use in laboratory research. ${ }^{156,165}$

\section{Conclusion and future directions}

The ultimate goal of reconstruction of urinary organs is not only anatomical but also functional. They are hollow, are elastic, and can be seeded with the similar cell types. The bladder is the most sophisticated to mimic, structurally and dynamically. On the other hand, the urethra, ureters, and neo-conduits are geometrically simpler to refashion as tubes.

Despite the enthusiasm and achievements so far, there is no "ideal biomaterial" available yet. Modification of biomaterial nanostructure will enhance its biological properties for cellular integration. Accordingly, successful tissue remodeling will be achieved. Smart polymers need to be explored even further to optimize their use in urinary reconstruction. They can be custom-made to change their shape and response when contacting urine. 3D bioprinting can further integrate sophisticated imaging techniques such as optical coherence tomography (OCT). OCT should be able to scan the depth of tissues on the ultra-molecular scale.

Overall, the field of tissue engineering is growing fast, implementing modern machinery to achieve its goal. The future might reveal definitive time-saving solutions, for example, intraoperative scanning of tissue defects with a "real time 3D bioprinting" using autologous tissues to reconstruct the diseased segments. 


\section{Acknowledgments}

The authors thank Professor Anthony R Mundy and Miss Daniela E Andrich for their helpful comments and Dr Dina Okasha for proofreading the article and assisting with the figure. MME is sponsored by University of Alexandria/the Ministry of Higher Education, Government of Egypt. AdM is a coinvestigator of Engineering and Physical Sciences Research Council (EPSRC) project EP/L020904/1.

\section{Disclosure}

The authors report no conflicts of interest in this work.

\section{References}

1. Woodhouse CR. Reconstructive urology. Curr Opin Urol. 2009; 19(6):555.

2. Sievert KD, Seibold J, Schultheiss D, et al. Rekonstruktive Urologie im Wandel [Reconstructive urology in transition. From its origin into the all too near future]. Urologe A. 2006;45(Suppl 4):52-58. German.

3. Damaser MS, Sievert KD. Tissue engineering and regenerative medicine: bench to bedside in urology. Preface. Adv Drug Deliv Rev. 2015;82-83:v-vii.

4. Albersen M, Cartwright R, Choyke P, et al. Looking forward, looking back - 10 years in urology. Nat Rev Urol. 2014;11(11):649-655.

5. Jordan GH. Principles of tissue transfer techniques in urethral reconstruction. Urol Clin North Am. 2002;29(2):267-275.

6. Bryk DJ, Yamaguchi Y, Zhao LC. Tissue transfer techniques in reconstructive urology. Korean J Urol. 2015;56(7):478-486.

7. Traxel EJ, Minevich EA, Noh PH. A review: the application of minimally invasive surgery to pediatric urology: lower urinary tract reconstructive procedures. Urology. 2010;76(1):115-120.

8. Mundy AR. The future of urology. BJU Int. 2003;92(4):337-339.

9. Zhang C, Murphy SV, Atala A. Regenerative medicine in urology. Semin Pediatr Surg. 2014;23(3):106-111.

10. O'Brien FJ. Biomaterials \& scaffolds for tissue engineering. Mater Today. 2011;14(3):88-95.

11. Ulery BD, Nair LS, Laurencin CT. Biomedical applications of biodegradable polymers. J Polym Sci B Polym Phys. 2011;49(12):832-864.

12. Feng C, Xu YM, Fu Q, Zhu WD, Cui L, Chen J. Evaluation of the biocompatibility and mechanical properties of naturally derived and synthetic scaffolds for urethral reconstruction. J Biomed Mater Res A. 2010;94(1):317-325

13. Beiko DT, Knudsen BE, Watterson JD, Cadieux PA, Reid G, Denstedt JD. Urinary tract biomaterials. J Urol. 2004;171(6 Pt 1):2438-2444.

14. Atala A, Bauer SB, Soker S, Yoo JJ, Retik AB. Tissue-engineered autologous bladders for patients needing cystoplasty. Lancet. 2006; 367(9518):1241-1246.

15. Adamowicz J, Juszczak K, Bajek A, et al. Morphological and urodynamic evaluation of urinary bladder wall regeneration: muscles guarantee contraction but not proper function - a rat model research study. Transplant Proc. 2012;44(5):1429-1434.

16. Lu SH, Sacks MS, Chung SY, et al. Biaxial mechanical properties of muscle-derived cell seeded small intestinal submucosa for bladder wall reconstitution. Biomaterials. 2005;26(4):443-449.

17. Ribeiro-Filho LA, Sievert KD. Acellular matrix in urethral reconstruction. Adv Drug Deliv Rev. 2015;82-83:38-46.

18. Vaegler M, Maurer S, Toomey P, Amend B, Sievert KD. Tissue engineering in urothelium regeneration. Adv Drug Deliv Rev. 2015; 82-83:64-68.

19. Lin HK, Madihally SV, Palmer B, Frimberger D, Fung KM, Kropp BP. Biomatrices for bladder reconstruction. Adv Drug Deliv Rev. 2015;82-83:47-63.
20. Yan Y, Wang X, Xiong Z, et al. Direct construction of a three-dimensional structure with cells and hydrogel. $J$ Bioact Compat Polym. 2005;20(3):259-269.

21. Jia J, Richards DJ, Pollard S, et al. Engineering alginate as bioink for bioprinting. Acta Biomater. 2014;10(10):4323-4331.

22. Chung BI, Hamawy KJ, Zinman LN, Libertino JA. The use of bowel for ureteral replacement for complex ureteral reconstruction: long-term results. J Urol. 2006;175(1):179-183.

23. Dahms SE, Piechota HJ, Dahiya R, Lue TF, Tanagho EA. Composition and biomechanical properties of the bladder acellular matrix graft: comparative analysis in rat, pig and human. $\mathrm{Br} J$ Urol. 1998;82(3):411-419.

24. Zhe Z, Jun D, Yang Z, et al. Bladder acellular matrix grafts seeded with adipose-derived stem cells and incubated intraperitoneally promote the regeneration of bladder smooth muscle and nerve in a rat model of bladder augmentation. Stem Cells Dev. 2016;25:405-414.

25. Liao W, Yang S, Song C, Li X, Li Y, Xiong Y. Construction of ureteral grafts by seeding bone marrow mesenchymal stem cells and smooth muscle cells into bladder acellular matrix. Transplant Proc. 2013;45(2):730-734.

26. Meng L, Liao W, Yang S, Xiong Y, Song C, Liu L. Tissue-engineered tubular substitutions for urinary diversion in a rabbit model. Exp Biol Med (Maywood). 2016;241(2):147-156.

27. Li CL, Liao WB, Yang SX, et al. Urethral reconstruction using bone marrow mesenchymal stem cell- and smooth muscle cell-seeded bladder acellular matrix. Transplant Proc. 2013;45(9):3402-3407.

28. Cheng EY, Kropp BP. Urologic tissue engineering with smallintestinal submucosa: potential clinical applications. World J Urol. 2000;18(1):26-30.

29. Lin HK, Godiwalla SY, Palmer B, et al. Understanding roles of porcine small intestinal submucosa in urinary bladder regeneration: identification of variable regenerative characteristics of small intestinal submucosa. Tissue Eng Part B Rev. 2014;20(1):73-83.

30. Wang F, Liu T, Yang L, et al. Urethral reconstruction with tissueengineered human amniotic scaffold in rabbit urethral injury models. Med Sci Monit. 2014;20:2430-2438.

31. Feng $\mathrm{C}, \mathrm{Xu} \mathrm{YM}, \mathrm{Fu} \mathrm{Q}, \mathrm{Zhu}$ WD, Cui L. Reconstruction of threedimensional neourethra using lingual keratinocytes and corporal smooth muscle cells seeded acellular corporal spongiosum. Tissue Eng Part A. 2011;17(23-24):3011-3019.

32. Song L, Murphy SV, Yang B, Xu Y, Zhang Y, Atala A. Bladder acellular matrix and its application in bladder augmentation. Tissue Eng Part $B$ Rev. 2014;20(2):163-172.

33. Feng C, Xu YM, Fu Q, Zhu WD, Cui L, Chen J. Evaluation of the biocompatibility and mechanical properties of naturally derived and synthetic scaffolds for urethral reconstruction. J Biomed Mater Res A. 2010;94(1):317-325.

34. Sack BS, Mauney JR, Estrada CR Jr. Silk fibroin scaffolds for urologic tissue engineering. Curr Urol Rep. 2016;17(2):16.

35. Xie M, Xu Y, Song L, Wang J, Lv X, Zhang Y. Tissue-engineered buccal mucosa using silk fibroin matrices for urethral reconstruction in a canine model. J Surg Res. 2014;188(1):1-7.

36. Wang Y, Rudym DD, Walsh A, et al. In vivo degradation of three-dimensional silk fibroin scaffolds. Biomaterials. 2008;29(24-25):3415-3428.

37. Kim UJ, Park J, Kim HJ, Wada M, Kaplan DL. Three-dimensional aqueous-derived biomaterial scaffolds from silk fibroin. Biomaterials. 2005;26(15):2775-2785.

38. Tu DD, Chung YG, Gil ES, et al. Bladder tissue regeneration using acellular bi-layer silk scaffolds in a large animal model of augmentation cystoplasty. Biomaterials. 2013;34(34):8681-8689.

39. Chung YG, Tu D, Franck D, et al. Acellular bi-layer silk fibroin scaffolds support tissue regeneration in a rabbit model of onlay urethroplasty. PLoS One. 2014;9(3):e91592.

40. Huang JW, Xu YM, Li ZB, et al. Tissue performance of bladder following stretched electrospun silk fibroin matrix and bladder acellular matrix implantation in a rabbit model. $J$ Biomed Mater Res A. 2016;104(1):9-16. 
41. Wang YL, Gu XM, Kong Y, Feng QL, Yang YM. Electrospun and woven silk fibroin/poly(lactic-co-glycolic acid) nerve guidance conduits for repairing peripheral nerve injury. Neural Regen Res. 2015;10(10):1635-1642.

42. Aitken KJ, Bagli DJ. The bladder extracellular matrix. Part I: architecture, development and disease. Nat Rev Urol. 2009;6(11):596-611.

43. Aitken KJ, Bagli DJ. The bladder extracellular matrix. Part II: regenerative applications. Nat Rev Urol. 2009;6(11):612-621.

44. Horst M, Madduri S, Milleret V, Sulser T, Gobet R, Eberli D. A bilayered hybrid microfibrous PLGA-acellular matrix scaffold for hollow organ tissue engineering. Biomaterials. 2013;34(5):1537-1545.

45. Lawrence BJ, Maase EL, Lin HK, Madihally SV. Multilayer composite scaffolds with mechanical properties similar to small intestinal submucosa. J Biomed Mater Res A. 2009;88(3):634-643.

46. Imani R, Pazoki M, Zupancic D, et al. Biocompatibility of different nanostructured $\mathrm{TiO}_{2}$ scaffolds and their potential for urologic applications. Protoplasma. 2015;253:1439-1447.

47. Chun YW, Lim H, Webster TJ, Haberstroh KM. Nanostructured bladder tissue replacements. Wiley Interdiscip Rev Nanomed Nanobiotechnol. 2011;3(2):134-145.

48. Yang Y, Leong KW. Nanoscale surfacing for regenerative medicine. Wiley Interdiscip Rev Nanomed Nanobiotechnol. 2010;2(5): 478-495.

49. Khang D, Lu J, Yao C, Haberstroh KM, Webster TJ. The role of nanometer and sub-micron surface features on vascular and bone cell adhesion on titanium. Biomaterials. 2008;29(8):970-983.

50. Gao J, Niklason L, Langer R. Surface hydrolysis of poly(glycolic acid) meshes increases the seeding density of vascular smooth muscle cells. J Biomed Mater Res. 1998;42(3):417-424.

51. Yang X, Zhao K, Chen GQ. Effect of surface treatment on the biocompatibility of microbial polyhydroxyalkanoates. Biomaterials. 2002;23(5):1391-1397.

52. Mazzoli A, Ferretti C, Gigante A, Salvolini E, Mattioli-Belmonte M. Selective laser sintering manufacturing of polycaprolactone bone scaffolds for applications in bone tissue engineering. Rapid Prototyp J. 2015;21(4):386-392.

53. Brehmer B, Rohrmann D, Becker C, Rau G, Jakse G. Different types of scaffolds for reconstruction of the urinary tract by tissue engineering. Urol Int. 2007;78(1):23-29.

54. Murphy CM, Duffy GP, Schindeler A, O’Brien FJ. Effect of collagenglycosaminoglycan scaffold pore size on matrix mineralization and cellular behavior in different cell types. J Biomed Mater Res A. 2016;104:291-304

55. Dorati R, Colonna C, Tomasi C, Genta I, Bruni G, Conti B. Design of 3D scaffolds for tissue engineering testing a tough polylactide-based graft copolymer. Mater Sci Eng C Mater Biol Appl. 2014;34:130-139.

56. Loh QL, Choong C. Three-dimensional scaffolds for tissue engineering applications: role of porosity and pore size. Tissue Eng Part B Rev. 2013;19(6):485-502.

57. Chun YW, Khang D, Haberstroh KM, Webster TJ. The role of polymer nanosurface roughness and submicron pores in improving bladder urothelial cell density and inhibiting calcium oxalate stone formation. Nanotechnology. 2009;20(8):085104.

58. Rnjak-Kovacina J, Weiss AS. Increasing the pore size of electrospun scaffolds. Tissue Eng Part B Rev. 2011;17(5):365-372.

59. Puppi D, Zhang X, Yang L, Chiellini F, Sun X, Chiellini E. Nano/ microfibrous polymeric constructs loaded with bioactive agents and designed for tissue engineering applications: a review. J Biomed Mater Res B Appl Biomater. 2014;102(7):1562-1579.

60. Giannitelli SM, Accoto D, Trombetta M, Rainer A. Current trends in the design of scaffolds for computer-aided tissue engineering. Acta Biomater. 2014;10(2):580-594.

61. Melchels FPW, Domingos MAN, Klein TJ, Malda J, Bartolo PJ, Hutmacher DW. Additive manufacturing of tissues and organs. Prog Polym Sci. 2012;37(8):1079-1104.

62. Giannitelli SM, Mozetic P, Trombetta M, Rainer A. Combined additive manufacturing approaches in tissue engineering. Acta Biomater. 2015;24:1-11.
63. Dorj B, Park J-H, Kim H-W. Robocasting chitosan/nanobioactive glass dual-pore structured scaffolds for bone engineering. Mater Lett. 2012;73:119-122.

64. Zhu N, Li MG, Cooper D, Chen XB. Development of novel hybrid poly(L-lactide)/chitosan scaffolds using the rapid freeze prototyping technique. Biofabrication. 2011;3(3):034105.

65. Kim MS, Kim G. Electrohydrodynamic jet process for pore-structurecontrolled 3D fibrous architecture as a tissue regenerative material: fabrication and cellular activities. Langmuir. 2014;30(28):8551-8557.

66. Kim M, Kim G. Physical and biological activities of newly designed, macro-pore-structure-controlled 3D fibrous poly( $\varepsilon$-caprolactone)/ hydroxyapatite composite scaffolds. RSCAdv. 2015;5(34):26954-26964.

67. Farrugia BL, Brown TD, Upton Z, Hutmacher DW, Dalton PD, Dargaville TR. Dermal fibroblast infiltration of poly( $\varepsilon$-caprolactone) scaffolds fabricated by melt electrospinning in a direct writing mode. Biofabrication. 2013;5(2):025001.

68. Brown TD, Slotosch A, Thibaudeau L, et al. Design and fabrication of tubular scaffolds via direct writing in a melt electrospinning mode. Biointerphases. 2012;7(1):1-16.

79. Brown TD, Dalton PD, Hutmacher DW. Direct writing by way of melt electrospinning. Adv Mater. 2011;23(47):5651-5657.

70. Billiet T, Vandenhaute M, Schelfhout J, Van Vlierberghe S, Dubruel P. A review of trends and limitations in hydrogel-rapid prototyping for tissue engineering. Biomaterials. 2012;33(26):6020-6041

71. Mauney JR, Adam RM. Dynamic reciprocity in cell-scaffold interactions. Adv Drug Deliv Rev. 2015;82-83:77-85.

72 Kanematsu A, Yamamoto S, Noguchi T, Ozeki M, Tabata Y, Ogawa O. Bladder regeneration by bladder acellular matrix combined with sustained release of exog- enous growth factor. $J$ Urol. 2003;170:1633-1638.

73 Mondalek FG, Ashley RA, Roth CC, et al. Enhanced angiogenesis of modified porcine small intestinal submucosa with hyaluronic acid-poly(lactide-co-glycolide) nanoparticles: from fabrication to preclinical validation. J Biomed. Mater Res. 2010;A 94;712-719.

74. Rice JJ, Martino MM, De Laporte L, Tortelli F, Briquez PS, Hubbell JA. Engineering the regenerative microenvironment with biomaterials. Adv Healthc Mater. 2013;2(1):57-71.

75. Sharma AK, Cheng EY. Growth factor and small molecule influence on urological tissue regeneration utilizing cell seeded scaffolds. $A d v$ Drug Deliv Rev. 2015;82-83:86-92.

76. Chen W, Shi C, Hou X, Zhang W, Li L. Bladder acellular matrix conjugated with basic fibroblast growth factor for bladder regeneration. Tissue Eng Part A. 2014;20(15-16):2234-2242.

77. Roth CC, Mondalek FG, Kibar Y, et al. Bladder regeneration in a canine model using hyaluronic acid-poly(lactic-co-glycolic-acid) nanoparticle modified porcine small intestinal submucosa. BJU Int. 2011;108(1):148-155.

78. Jiang X, Xiong Q, Xu G, et al. VEGF-loaded nanoparticle-modified BAMAs enhance angiogenesis and inhibit graft shrinkage in tissueengineered bladder. Ann Biomed Eng. 2015;43(10):2577-2586.

79. Lorentz KM, Yang L, Frey P, Hubbell JA. Engineered insulin-like growth factor-1 for improved smooth muscle regeneration. Biomaterials. 2012;33(2):494-503.

80. Bauer SM, Bauer RJ, Liu ZJ, Chen H, Goldstein L, Velazquez OC. Vascular endothelial growth factor-C promotes vasculogenesis, angiogenesis, and collagen constriction in three-dimensional collagen gels. J Vasc Surg. 2005;41(4):699-707.

81. Kikuno N, Kawamoto K, Hirata H, et al. Nerve growth factor combined with vascular endothelial growth factor enhances regeneration of bladder acellular matrix graft in spinal cord injury-induced neurogenic rat bladder. BJU Int. 2009;103(10):1424-1428.

82. Youssif M, Shiina H, Urakami S, et al. Effect of vascular endothelial growth factor on regeneration of bladder acellular matrix graft: histologic and functional evaluation. Urology. 2005;66(1):201-207.

83. Xiong $\mathrm{Q}$, Lin $\mathrm{H}, \mathrm{Hua} \mathrm{X}$, et al. A nanomedicine approach to effectively inhibit contracture during bladder acellular matrix allograft-induced bladder regeneration by sustained delivery of vascular endothelial growth factor. Tissue Eng Part A. 2015;21(1-2):45-52. 
84. Yang B, Zhou L, Peng B, Sun Z, Dai Y, Zheng J. In vitro comparative evaluation of recombinant growth factors for tissue engineering of bladder in patients with neurogenic bladder. J Surg Res. 2014; 186(1):63-72.

85. Sharma AK, Bury MI, Fuller NJ, et al. Growth factor release from a chemically modified elastomeric poly(1,8-octanediol-co-citrate) thin film promotes angiogenesis in vivo. $J$ Biomed Mater Res A. 2012;100(3):561-570.

86. Storrie H, Guler MO, Abu-Amara SN, et al. Supramolecular crafting of cell adhesion. Biomaterials. 2007;28(31):4608-4618.

87. Pierschbacher MD, Ruoslahti E. Cell attachment activity of fibronectin can be duplicated by small synthetic fragments of the molecule. Nature. 1984;309(5963):30-33.

88. Harrington DA, Cheng EY, Guler MO, et al. Branched peptide-amphiphiles as self-assembling coatings for tissue engineering scaffolds. $J$ Biomed Mater Res A. 2006;78(1):157-167.

89. Kearns VR, McMurray RJ, Dalby MJ. Biomaterial surface topography to control cellular response: technologies, cell behaviour and biomedical applications. In: Williams R, editor. Surface Modification of Biomaterials. Woodhead Publishing; 2011:169-201.

90. Uchida N, Sivaraman S, Amoroso NJ, et al. Nanometer-sized extracellular matrix coating on polymer-based scaffold for tissue engineering applications. J Biomed Mater Res A. 2016;104:94-103.

91. Garcia-Garcia JM, Lopez L, Paris R, et al. Surface modification of poly(3-hydroxybutyrate-co-3-hydroxyvalerate) copolymer films for promoting interaction with bladder urothelial cells. J Biomed Mater Res A. 2012;100(1):7-17.

92. Garcia-Garcia JM, Quijada-Garrido I, Lopez L, et al. The surface modification of poly(3-hydroxybutyrate-co-3-hydroxyhexanoate) copolymers to improve the attachment of urothelial cells. Mater Sci Eng C Mater Biol Appl. 2013;33(1):362-369.

93. Chu PK, Chen JY, Wang LP, Huang N. Plasma-surface modification of biomaterials. Mater Sci Eng R Rep. 2002;36(5-6):143-206.

94. Yoshida S, Hagiwara K, Hasebe T, Hotta A. Surface modification of polymers by plasma treatments for the enhancement of biocompatibility and controlled drug release. Surf Coat Technol. 2013;233: 99-107.

95. Pandiyaraj KN, Deshmukh RR, Mahendiran R, et al. Influence of operating parameters on surface properties of RF glow discharge oxygen plasma treated $\mathrm{TiO}_{2} / \mathrm{PET}$ film for biomedical application. Mater Sci Eng C Mater Biol Appl. 2014;36:309-319.

96. DeLong SA, Moon JJ, West JL. Covalently immobilized gradients of bFGF on hydrogel scaffolds for directed cell migration. Biomaterials. 2005;26(16):3227-3234.

97. Masters KS, Shah DN, Walker G, Leinwand LA, Anseth KS. Designing scaffolds for valvular interstitial cells: cell adhesion and function on naturally derived materials. J Biomed Mater Res A. 2004;71(1):172-180.

98. Gobin AS, West JL. Val-ala-pro-gly, an elastin-derived non-integrin ligand: smooth muscle cell adhesion and specificity. J Biomed Mater Res A. 2003;67(1):255-259.

99. Baroli B. Photopolymerization of biomaterials: issues and potentialities in drug delivery, tissue engineering, and cell encapsulation applications. J Chem Technol Biotechnol. 2006;81(4):491-499.

100. Zakrzewski JL, van den Brink MR, Hubbell JA. Overcoming immunological barriers in regenerative medicine. Nat Biotechnol. 2014;32(8):786-794.

101. Zhang Y, Atala A. Urothelial cell culture: stratified urothelial sheet and three-dimensional growth of urothelial structure. Methods Mol Biol. 2013;945:383-399.

102. Kloskowski T, Uzarska M, Gurtowska N, et al. How to isolate urothelial cells? Comparison of four different methods and literature review. Hum Cell. 2014;27(2):85-93.

103. Basu J, Jayo MJ, Ilagan RM, et al. Regeneration of native-like neourinary tissue from nonbladder cell sources. Tissue Eng A. 2012; 18(9-10):1025-1034.

104. Drewa T, Adamowicz J, Sharma A. Tissue engineering for the oncologic urinary bladder. Nat Rev Urol. 2012;9(10):561-572.
105. Subramaniam R, Hinley J, Stahlschmidt J, Southgate J. Tissue engineering potential of urothelial cells from diseased bladders. $J$ Urol. 2011;186(5):2014-2020.

106. Osman NI, Hillary C, Bullock AJ, MacNeil S, Chapple CR. Tissue engineered buccal mucosa for urethroplasty: progress and future directions. Adv Drug Deliv Rev. 2015;82-83:69-76.

107. Mikami H, Kuwahara G, Nakamura N, Yamato M, Tanaka M, Kodama S. Two-layer tissue engineered urethra using oral epithelial and muscle derived cells. J Urol. 2012;187(5):1882-1889.

108. Barbagli G, Ram Liebig G, Fahlenkamp D, Lazzeri M. New bulbar urethroplasty using tissue-engineered oral mucosal graft: a preliminary clinical report. J Urol. 2013;189(4 Suppl):e1.

109. Mousa NA, Abou-Taleb HA, Orabi H. Stem cell applications for pathologies of the urinary bladder. World J Stem Cells. 2015;7(5):815-822.

110. Stoltz JF, de Isla N, Li YP, et al. Stem cells and regenerative medicine: myth or reality of the 21th century. Stem Cells Int. 2015;2015:734731.

111. Jiang Y, Jahagirdar BN, Reinhardt RL, et al. Pluripotency of mesenchymal stem cells derived from adult marrow. Nature. 2002;418(6893):41-49.

112. Sterodimas A, de Faria J, Nicaretta B, Pitanguy I. Tissue engineering with adipose-derived stem cells (ADSCs): current and future applications. J Plast Reconstr Aesthet Surg. 2010;63(11):1886-1892.

113. Bharadwaj S, Liu G, Shi Y, et al. Multipotential differentiation of human urine-derived stem cells: potential for therapeutic applications in urology. Stem Cells. 2013;31(9):1840-1856.

114. Zhang D, Wei G, Li P, Zhou X, Zhang Y. Urine-derived stem cells: a novel and versatile progenitor source for cell-based therapy and regenerative medicine. Genes Dis. 2014;1(1):8-17.

115. Moad M, Pal D, Hepburn AC, et al. A novel model of urinary tract differentiation, tissue regeneration, and disease: reprogramming human prostate and bladder cells into induced pluripotent stem cells. Eur Urol. 2013;64(5):753-761.

116. Smolar J, Salemi S, Horst M, Sulser T, Eberli D. Stem cells in functional bladder engineering. Transfus Med Hemother. 2016;43(5):328-335.

117. Lang R, Liu G, Shi Y, et al. Self-renewal and differentiation capacity of urine-derived stem cells after urine preservation for 24 hours. PLoS One. 2013;8(1):e53980.

118. Zhang Y, McNeill E, Tian H, et al. Urine derived cells are a potential source for urological tissue reconstruction. J Urol. 2008;180(5):2226-2233.

119. Bodin A, Bharadwaj S, Wu S, Gatenholm P, Atala A, Zhang Y. Tissueengineered conduit using urine-derived stem cells seeded bacterial cellulose polymer in urinary reconstruction and diversion. Biomaterials. 2010;31(34):8889-8901.

120. Kanematsu A, Yamamoto S, Iwai-Kanai E, et al. Induction of smooth muscle cell-like phenotype in marrow-derived cells among regenerating urinary bladder smooth muscle cells. Am J Pathol. 2005;166(2):565-573.

121. Hu J, Tian L, Prabhakaran M, Ding X, Ramakrishna S. Fabrication of nerve growth factor encapsulated aligned poly( $\varepsilon$-caprolactone) nanofibers and their assessment as a potential neural tissue engineering scaffold. Polymers. 2016;8(2):54.

122. Heyns CF. Urinary tract infection associated with conditions causing urinary tract obstruction and stasis, excluding urolithiasis and neuropathic bladder. World J Urol. 2012;30(1):77-83.

123. Mohammad-Jafari H, Saffar MJ, Nemate I, Saffar H, Khalilian AR. Increasing antibiotic resistance among uropathogens isolated during years 2006-2009: impact on the empirical management. Int Braz J Urol. 2012;38(1):25-32.

124. Zowawi HM, Harris PN, Roberts MJ, et al. The emerging threat of multidrug-resistant Gram-negative bacteria in urology. Nat Rev Urol. 2015;12(10):570-584.

125. Shameli K, Ahmad MB, Zargar M, Yunus WM, Rustaiyan A, Ibrahim NA. Synthesis of silver nanoparticles in montmorillonite and their antibacterial behavior. Int J Nanomedicine. 2011;6:581-590.

126. Stickler DJ. Clinical complications of urinary catheters caused by crystalline biofilms: something needs to be done. J Intern Med. 2014;276(2):120-129. 
127. Hoiby N, Ciofu O, Johansen HK, et al. The clinical impact of bacterial biofilms. Int J Oral Sci. 2011;3(2):55-65.

128. Schaffer JN, Pearson MM. Proteus mirabilis and urinary tract infections. Microbiol Spectr. 2015;3(5).

129. Sighinolfi MC, Sighinolfi GP, Galli E, et al. Chemical and mineralogical analysis of ureteral stent encrustation and associated risk factors. Urology. 2015;86(4):703-706.

130. Bouzidi H, Traxer O, Dore B, et al. Caractéristiques des incrustations des endoprothèses urétérales chez les patients lithiasiques [Characteristics of encrustation of ureteric stents in patients with urinary stones]. Prog Urol. 2008;18(4):230-237. French.

131. Bithelis G, Bouropoulos N, Liatsikos EN, Perimenis P, Koutsoukos PG, Barbalias GA. Assessment of encrustations on polyurethane ureteral stents. J Endourol. 2004;18(6):550-556.

132. Anselme K, Davidson P, Popa AM, Giazzon M, Liley M, Ploux L. The interaction of cells and bacteria with surfaces structured at the nanometre scale. Acta Biomater. 2010;6(10):3824-3846.

133. Garrett TR, Bhakoo M, Zhang Z. Bacterial adhesion and biofilms on surfaces. Prog Nat Sci. 2008;18(9):1049-1056.

134. Hori K, Matsumoto S. Bacterial adhesion: from mechanism to control. Biochem Eng J. 2010;48(3):424-434.

135. Rai M, Ingle AP, Gupta I, Brandelli A. Bioactivity of noble metal nanoparticles decorated with biopolymers and their application in drug delivery. Int J Pharm. 2015;496(2):159-172.

136. Li X, Robinson SM, Gupta A, et al. Functional gold nanoparticles as potent antimicrobial agents against multi-drug-resistant bacteria. $A C S$ Nano. 2014;8(10):10682-10686.

137. Roe D, Karandikar B, Bonn-Savage N, Gibbins B, Roullet JB. Antimicrobial surface functionalization of plastic catheters by silver nanoparticles. J Antimicrob Chemother. 2008;61(4):869-876.

138. Kishikawa H, Ebberyd A, Römling U, et al. Control of pathogen growth and biofilm formation using a urinary catheter that releases antimicrobial nitrogen oxides. Free Radic Biol Med. 2013;65:1257-1264.

139. Regev-Shoshani G, Ko M, Miller C, Av-Gay Y. Slow release of nitric oxide from charged catheters and its effect on biofilm formation by Escherichia coli. Antimicrob Agents Chemother. 2010;54(1):273-279.

140. Colletta A, Wu J, Wo Y, et al. S-Nitroso-N-acetylpenicillamine (SNAP) impregnated silicone foley catheters: a potential biomaterial/device to prevent catheter-associated urinary tract infections. ACS Biomater Sci Eng. 2015;1(6):416-424.

141. de Mel, Murad F, Seifalian AM. Nitric oxide: a guardian for vascular grafts? Chem Rev. 2011;111(9):5742-5767.

142. Ribeiro C, Sencadas V, Correia DM, Lanceros-Méndez S. Piezoelectric polymers as biomaterials for tissue engineering applications. Colloids Surf B Biointerfaces. 2015;136:46-55.

143. Aguilar MR, San Román J. Introduction to smart polymers and their applications. In: Aguilar MR, Román JS, editors. Smart Polymers and Their Applications. Woodhead Publishing; 2014:1-11.

144. Hardy JG, Palma M, Wind SJ, Biggs MJ. Responsive biomaterials: advances in materials based on shape-memory polymers. Adv Mater. 2016;28(27):5717-5724.

145. Kulkarni R, Bellamy E. Nickel-titanium shape memory alloy Memokath 051 ureteral stent for managing long-term ureteral obstruction: 4-year experience. J Urol. 2001;166(5):1750-1754.

146. Perry MJ, Roodhouse AJ, Gidlow AB, Spicer TG, Ellis BW. Thermoexpandable intraprostatic stents in bladder outlet obstruction: an 8-year study. BJU Int. 2002;90(3):216-223.

147. Rickert D, Moses MA, Lendlein A, Kelch S, Franke RP. The importance of angiogenesis in the interaction between polymeric biomaterials and surrounding tissue. Clin Hemorheol Microcirc. 2003;28(3):175-181.

148. Tzoneva R, Seifert B, Behl M, Lendlein A. Elastic multiblock copolymers for vascular regeneration: protein adsorption and hemocompatibility. Clin Hemorheol Microcirc. 2012;52(2-4):337-348.

149. Correia CO, Leite AJ, Mano JF. Chitosan/bioactive glass nanoparticles scaffolds with shape memory properties. Carbohydr Polym. 2015;123:39-45.
150. Fu YQ, Huang WM, Luo JK, Lu H. Polyurethane shape-memory polymers for biomedical applications. In: Yahia L, editor. Shape Memory Polymers for Biomedical Applications. Woodhead Publishing; 2015:167-195.

151. Hardy J, Cornelison R, Sukhavasi R, et al. Electroactive tissue scaffolds with aligned pores as instructive platforms for biomimetic tissue engineering. Bioengineering. 2015;2(1):15.

152. Wu Y, Wang L, Guo B, Shao Y, Ma PX. Electroactive biodegradable polyurethane significantly enhanced Schwann cells myelin gene expression and neurotrophin secretion for peripheral nerve tissue engineering. Biomaterials. 2016;87:18-31.

153. Ahyai SA, Schmid M, Kuhl M, et al. Outcomes of ventral onlay buccal mucosa graft urethroplasty in patients after radiotherapy. $J$ Urol. 2015;194(2):441-446.

154. Stolting MN, Arnold AS, Haralampieva D, Handschin C, Sulser T, Eberli D. Magnetic stimulation supports muscle and nerve regeneration after trauma in mice. Muscle Nerve. 2016;53(4):598-607.

155. Shi Z, Gao X, Ullah MW, Li S, Wang Q, Yang G. Electroconductive natural polymer-based hydrogels. Biomaterials. 2016;111:40-54.

156. Murphy SV, Atala A. 3D bioprinting of tissues and organs. Nat Biotechnol. 2014;32(8):773-785.

157. Kang HW, Lee SJ, Ko IK, Kengla C, Yoo JJ, Atala A. A 3D bioprinting system to produce human-scale tissue constructs with structural integrity. Nat Biotechnol. 2016;34:312-319.

158. Jung JW, Lee JS, Cho DW. Computer-aided multiple-head 3D printing system for printing of heterogeneous organ/tissue constructs. Sci Rep. 2016;6:21685.

159. Pati F, Jang J, Ha DH, et al. Printing three-dimensional tissue analogues with decellularized extracellular matrix bioink. Nat Commun. 2014;5.

160. Youssef RF, Spradling K, Yoon R, et al. Applications of threedimensional printing technology in urological practice. BJU Int. 2015;116:697-702.

161. Priester A, Natarajan S, Le JD, et al. A system for evaluating magnetic resonance imaging of prostate cancer using patient-specific $3 \mathrm{D}$ printed molds. Am J Clin Exp Urol. 2014;2(2):127-135.

162. Cheung CL, Looi T, Lendvay TS, Drake JM, Farhat WA. Use of 3-dimensional printing technology and silicone modeling in surgical simulation: development and face validation in pediatric laparoscopic pyeloplasty. J Surg Educ. 2014;71(5):762-767.

163. Soliman Y, Feibus AH, Baum N. 3D printing and its urologic applications. Rev Urol. 2015;17(1):20-24.

164. Zhang K, Fu Q, Yoo J, et al. 3D bioprinting of urethra with PCL/PLCL blend and dual autologous cells in fibrin hydrogel: an in vitro evaluation of biomimetic mechanical property and cell growth environment. Acta Biomater. 2017;50:154-164.

165. Wang X, Yan Y, Zhang R. Recent trends and challenges in complex organ manufacturing. Tissue Eng B Rev. 2010;16(2):189-197.

166. Mundy AR, Andrich DE. Urethral strictures. BJU Int. 2011;107(1): 6-26.

167. Craig JR, Wallis C, Brant WO, Hotaling JM, Myers JB. Management of adults with prior failed hypospadias surgery. Transl Androl Urol. 2014;3(2):196-204.

168. Mundy AR. Failed hypospadias repair presenting in adults. Eur Urol. 2006;49(5):774-776.

169. Andrich DE, Mundy AR. What is the best technique for urethroplasty? Eur Urol. 2008;54(5):1031-1041.

170. Andrich DE, Mundy AR. Non-transecting anastomotic bulbar urethroplasty: a preliminary report. BJU Int. 2012;109(7):1090-1094.

171. Kuo TL, Venugopal S, Inman RD, Chapple CR. Surgical tips and tricks during urethroplasty for bulbar urethral strictures focusing on accurate localisation of the stricture: results from a tertiary centre. Eur Urol. 2015;67(4):764-770.

172. Lumen N, Vierstraete-Verlinde S, Oosterlinck W, et al. Buccal versus lingual mucosa graft in anterior urethroplasty: a prospective comparison of surgical outcome and donor site morbidity. J Urol. 2016; 195:112-117. 
173. Mangera A, Patterson JM, Chapple CR. A systematic review of graft augmentation urethroplasty techniques for the treatment of anterior urethral strictures. Eur Urol. 2011;59(5):797-814.

174. Lumen N, Oosterlinck W, Hoebeke P. Urethral reconstruction using buccal mucosa or penile skin grafts: systematic review and metaanalysis. Urol Int. 2012;89(4):387-394.

175. Barbagli G, Vallasciani S, Romano G, Fabbri F, Guazzoni G, Lazzeri M. Morbidity of oral mucosa graft harvesting from a single cheek. Eur Urol. 2010;58(1):33-41.

176. Wood DN, Allen SE, Andrich DE, Greenwell TJ, Mundy AR. The morbidity of buccal mucosal graft harvest for urethroplasty and the effect of nonclosure of the graft harvest site on postoperative pain. $J$ Urol. 2004;172(2):580-583.

177. Biers SM, Venn SN, Greenwell TJ. The past, present and future of augmentation cystoplasty. BJU Int. 2012;109(9):1280-1293.

178. Cody JD, Nabi G, Dublin N, et al. Urinary diversion and bladder reconstruction/replacement using intestinal segments for intractable incontinence or following cystectomy. Cochrane Database Syst Rev. 2012;2:CD003306.
179. Lee RK, Abol-Enein H, Artibani W, et al. Urinary diversion after radical cystectomy for bladder cancer: options, patient selection, and outcomes. BJU Int. 2014;113(1):11-23.

180. Greenwell TJ, Venn SN, Mundy AR. Augmentation cystoplasty. BJU Int. 2001;88(6):511-525.

181. Stein R, Kamal MM, Rubenwolf P, Ziesel C, Schroder A, Thuroff JW. Bladder augmentation using bowel segments (enterocystoplasty). BJU Int. 2012;110(7):1078-1094.

182. Stein R, Schröder A, Thüroff JW. Bladder augmentation and urinary diversion in patients with neurogenic bladder: non-surgical considerations. J Pediatr Urol. 2012;8(2):145-152.

183. Stein R, Schröder A, Thüroff JW. Bladder augmentation and urinary diversion in patients with neurogenic bladder: surgical considerations. J Pediatr Urol. 2012;8(2):153-161.

184. Knight RB, Hudak SJ, Morey AF. Strategies for open reconstruction of upper ureteral strictures. Urol Clin North Am. 2013;40(3): 351-361.

185. Ali-el-Dein B, Ghoneim MA. Bridging long ureteral defects using the Yang-Monti principle. J Urol. 2003;169(3):1074-1077.
Research and Reports in Urology

\section{Publish your work in this journal}

Research and Reports in Urology is an international, peer-reviewed, open access journal publishing original research, reports, editorials, reviews and commentaries on all aspects of adult and pediatric urology in the clinic and laboratory including the following topics: Pathology, pathophysiology of urological disease; Investigation and treatment of

\section{Dovepress}

urological disease; Pharmacology of drugs used for the treatment of urological disease. The manuscript management system is completely online and includes a very quick and fair peer-review system, which is all easy to use. Visit http://www.dovepress.com/testimonials.php to read real quotes from published authors. 